Article

\title{
Impact of Milk Thistle (Silybum marianum [L.] Gaertn.) Seeds in Broiler Chicken Diets on Rearing Results, Carcass Composition, and Meat Quality
}

\author{
Alina Janocha, Anna Milczarek*(D) and Daria Pietrusiak \\ Institute of Animal Science and Fisheries, Faculty of Agrobioengineering and Animal Husbandry, \\ Siedlce University of Natural Sciences and Humanities, Bolesława Prusa 14, 08-110 Siedlce, Poland; \\ alina.janocha@uph.edu.pl (A.J.); dp335@stud.uph.edu.pl (D.P.) \\ * Correspondence: anna.milczarek@uph.edu.pl; Tel.: +48-25-643-13-77
}

check for updates

Citation: Janocha, A.; Milczarek, A.; Pietrusiak, D. Impact of Milk Thistle (Silybum marianum [L.] Gaertn.) Seeds in Broiler Chicken Diets on Rearing Results, Carcass Composition, and Meat Quality. Animals 2021, 11, 1550. https://doi.org/10.3390/ani11061550

Academic Editor: Colin Scanes

Received: 8 May 2021

Accepted: 25 May 2021

Published: 26 May 2021

Publisher's Note: MDPI stays neutral with regard to jurisdictional claims in published maps and institutional affiliations.

Copyright: (C) 2021 by the authors Licensee MDPI, Basel, Switzerland. This article is an open access article distributed under the terms and conditions of the Creative Commons Attribution (CC BY) license (https:// creativecommons.org/licenses/by/ $4.0 /)$.
Simple Summary: This study shows how introducing milk thistle seeds into broiler chicken feed rations affects rearing results (weight gain, intake and conversion of feed), carcass composition and meat quality ( $\mathrm{pH}$, color, water holding capacity), the chemical composition (basic components, fatty acids) and organoleptic properties (flavor, tenderness, palatability and juiciness) of meat. Based on the results the use of milk thistle seeds in broiler chicken starter/grower diets can be recommended in the amount of $0 / 2 \%$ or $2 / 3 \%$, respectively. However, the introduction of Silybum marianum in starter and grower rations (over the whole rearing period) made it possible to obtain the highest body weight at the lowest feed conversion per body weight gain unit, without influencing muscularity and fattening grade, at the same time improving the meat's value for health.

Abstract: The studies aimed to evaluate the impact of milk thistle seeds in broiler chicken feed rations on rearing results, carcass composition and meat quality. The experiment involved 120 broiler chickens randomly allocated to three equinumerous groups (C, MT02, MT23). Each group was divided into five subgroups of eight chickens each. Over the first 21 days of life the birds were fed starter rations, and over the following 21 days received grower rations. Chicken starter/grower diets in groups MT02 and MT23 were supplemented with ground seeds of milk thistle in the amount of $0 / 2 \%$ (MT02) and 2/3\% (MT23). It was demonstrated that Silybum marianum added to feed rations over the whole rearing period (group MT23) increased above $3 \%$ the birds' body weight on rearing day $42 .(p<0.05)$ and decreased about $7 \%$ the feed conversion ratio $(p<0.05)$ in comparison to group C. No effect of feeding on the carcass composition was observed, including on muscularity and fattening grade, although diets containing milk thistle reduced (by 15\% and 19\% in group MT02 and MT23, respectively) the content of crude fat in chicken leg muscles $(p<0.05)$. The highest $(p<0.05)$ content of polyunsaturated fatty acids (PUFA) was determined in the breast (38.06\%) and leg (37.63\%) muscles of chicken receiving feed rations containing Silybum marianum throughout the rearing period. No effect of nutrition on the evaluated physical properties of muscles was observed, except on the decrease in lightness color $\left(\mathrm{L}^{*}\right)$ and increase in values $\mathrm{a}^{*}$ and $\mathrm{C}$ as well as a decrease of water holding capacity of the breast muscles. It was found that Silybum marianum in chicken diets had a positive effect on the evaluated meat flavor characteristics of the muscles. To sum up, based on the study results, including ground seeds of milk thistle in broiler chickens nutrition can be recommended in the amount of $2 / 3 \%$ in starter/grower diets, respectively.

Keywords: milk thistle; rations; broiler chicken; performance results; carcass value; meat quality

\section{Introduction}

The European Union's prohibition of using antibiotics in feeds as growth stimulants made breeders and feed producers look for new nutritional solutions. Apart from 
probiotics, prebiotics, organic acids, antioxidants, and feed enzymes, various preparations of plant origin - so-called phytobiotics—have raised more and more interest [1-5]. Hippenstiel et al. [6] and Tavakolinasab et al. [7] report that herbs can be used in various forms: fresh or dried, infusion, brew, extract, essential oils and macerates.

Herbs and herbal preparations contain active biological ingredients, i.e.,: essential oils, tannins, glycosides, flavonoids, terpenes, mucilages, and organic acids [5,8-10]. Biological active components of herbal preparations display multi-directional activity: anti-stress, antibacterial, anti-virus, and anti-fungicidal [11,12]. In addition, they enhance the excretion of digestive enzymes increasing the appetite of animals $[8,13,14]$. They are believed "natural" and "safe" [12]. A positive impact of medicinal plants on the microflora of the digestive tract and productive performance of animals was demonstrated [4,15-17]. In the opinion of Gregačević et al. [18] phytogenic feed additives stimulate the immunological system, whereas the resistant stimulating effect of these additives is based on an increased activity of lymphocytes, macrophages, and cells.

Currently, milk thistle (Silybum marianum [L.] Gaertn) is increasingly popular in animal nutrition [9,19-21]. Milk thistle seeds have a different content of protein $(160-300 \mathrm{~g} / \mathrm{kg})$ containing a lot of exogenous amino acids, which is confirmed by EAAI-the essential amino acid index (60.32) [22-24]. Crude fat from milk thistle seeds has an advantageous composition of fatty acids with oleic and linoleic acid predominating [22,23,25-27]. A high content of cellulose and lignin fraction in the diets of monogastric animals can pose certain limitations [28]. The main biological active component of milk thistle seeds is silymarin accounting for 1.5-3\% [24,29]. Silymarin is composed of flavonolignans consisting of: silibinin $(60 \%)$, isosilibinin (5\%), silidianin $(20 \%)$ and silicristin $(10 \%)$, of which silibinin has the strongest effect [29-32]. Silymarin perfectly protects the liver from toxic agents and helps regenerate it [30,33]. In addition, it has an anti-inflammatory effect, inhibiting the migration of neutrophils and fostering the formation of prostaglandins [34-36]. Due to its medicinal properties, silymarin is preferred by veterinary doctors as a natural medicine and recommended for intensive animal production [7,37-40]. Therefore, milk thistle can be widely used for animal feeding and in veterinary medicine. However, the results of studies [20,41-44] differ. Št'astník et al. [43] demonstrated that using 5\% or $15 \%$ of milk thistle oil cake in the diets of broiler chickens can decrease their weight gain. Similarly, Gharahveysi [44] introducing $0.3 \%$ or $3 \%$ ground milk thistle into the birds' diets found a reduced feed intake and body weight of chickens. However, Muhammad et al. [42] and Ahmad et al. [20] showed an increase in body weight and feed conversion ratio in chickens fed diets containing 10 and $15 \mathrm{~g} / \mathrm{kg}$ of milk thistle, respectively. Tedesco et al. [31] and Mojahedtalab et al. [45] showed a positive effect of supplementing broiler chicken feed rations with silymarin-phospholipid complex or silymarin on the performance results. Similarly, the post-slaughter results of birds fed diets containing Silybum marianum do not unanimously show how it affects the carcass composition and meat quality, since available literature lacks an evaluation the physico-chemical and organoleptic characteristics of meat $[7,43,46-49]$.

The aim of the studies was to assess the effect of feeding different amounts of milk thistle seeds at different productive stages (starter and grower) on broiler productive performance, carcass composition, meat quality and sensory properties.

\section{Materials and Methods}

\subsection{Experiment Design}

The feeding experiment involved 120 Ross 308 sexed broiler chickens randomly allocated to three equinumerous groups (C, MT02, MT23). Each group was divided into five subgroups of eight chickens (4 males and 4 females) each. The birds were reared over a 42-day cycle in metal cages under standard microclimate conditions with unlimited access to water (nipple drinkers) and feed. A free feeding (ad libitum) scheme was used. Throughout the rearing period the birds were exposed to 24-hour electric lighting. In the first experimental week ambient temperature was $32{ }^{\circ} \mathrm{C}$, and was then decreased every 
week (every 7 days) by $1-2{ }^{\circ} \mathrm{C}$ until it reached $21-23{ }^{\circ} \mathrm{C}$ in the last rearing week. In the first rearing period, i.e., until day 21 , the birds were fed complete bulk starter feed rations and from day 22 to $42-$ with grower feed rations. All loose feed rations were based on wheat, soybean cake (non-GMO), soybean oil and mineral and vitamin additives. Chicken starter/grower diets in experimental groups (MT02 and MT23) were supplemented with ground seeds of milk thistle in the amount of $0 / 2 \%$ (MT02) and $2 / 3 \%$ (MT23). The nutrient content of the basal diet was calculated on the basis of the chemical composition of raw feedstuffs, and the metabolizable energy value was in line with equations from the European Tables [50]. The nutritional value of rations was calculated according to nutritional recommendations and indicated in Table 1.

Table 1. Composition and nutritive value of rations.

\begin{tabular}{|c|c|c|c|c|c|c|}
\hline \multirow{2}{*}{ Specification } & \multicolumn{3}{|c|}{ Starter } & \multicolumn{3}{|c|}{ Grower } \\
\hline & $\mathrm{C}$ & MT02 & MT23 & $\mathrm{C}$ & MT02 & MT23 \\
\hline \multicolumn{7}{|l|}{ Ingredients (g/kg) } \\
\hline Wheat & 598 & 598 & 618 & 608 & 628 & 618 \\
\hline Soybean cake & 360 & 360 & 320 & 330 & 290 & 290 \\
\hline Milk thistle & - & - & 20.0 & - & 20.0 & 30.0 \\
\hline Soybean oil & - & - & - & 20.0 & 20.0 & 20.0 \\
\hline Limestone & 11.5 & 11.5 & 11.0 & 10.8 & 11.7 & 11.7 \\
\hline $\mathrm{NaCl}$ & 3.50 & 3.50 & 3.50 & 3.50 & 3.50 & 3.50 \\
\hline 2-Ca phosphate & 18.5 & 18.5 & 18.0 & 18.5 & 17.3 & 17.3 \\
\hline Premix starter/grower * & 5.00 & 5.00 & 5.00 & 5.00 & 5.00 & 5.00 \\
\hline L-lysine $(99 \%)$ & 1.00 & 1.00 & 2.00 & 1.50 & 2.00 & 2.00 \\
\hline DL-methionine (99\%) & 2.50 & 2.50 & 2.50 & 2.70 & 2.50 & 2.50 \\
\hline \multicolumn{7}{|c|}{ Calculated nutritive value per $1 \mathrm{~kg}$ of diets } \\
\hline Metabolizable energy (MJ) & 13.0 & 13.0 & 13.0 & 13.3 & 13.4 & 13.4 \\
\hline Crude protein $(\mathrm{g})$ & 230 & 230 & 230 & 214 & 214 & 218 \\
\hline Lysine $(\mathrm{g})$ & 12.3 & 12.3 & 12.3 & 12.0 & 11.5 & 11.5 \\
\hline Methionine (g) & 5.65 & 5.65 & 5.46 & 5.69 & 5.30 & 5.28 \\
\hline Tryptophan (g) & 2.83 & 2.78 & 2.63 & 2.67 & 2.47 & 2.46 \\
\hline Ca total $(\mathrm{g})$ & 9.70 & 9.70 & 9.29 & 9.35 & 9.30 & 9.29 \\
\hline P available (g) & 4.38 & 4.38 & 4.24 & 4.33 & 4.08 & 4.07 \\
\hline $\mathrm{Na}(\mathrm{g})$ & 1.58 & 1.58 & 1.57 & 1.57 & 1.56 & 1.56 \\
\hline \multicolumn{7}{|c|}{ Analyzed nutrients (\%) } \\
\hline Dry matter & 89.0 & 90.0 & 90.0 & 89.3 & 89.7 & 89.7 \\
\hline Crude ash & 5.86 & 6.11 & 5.88 & 5.66 & 5.85 & 5.94 \\
\hline Crude protein & 23.3 & 23.0 & 23.0 & 21.3 & 21.1 & 21.8 \\
\hline Crude fat & 3.62 & 3.47 & 3.90 & 4.19 & 4.62 & 4.95 \\
\hline Crude fiber & 2.98 & 3.12 & 4.13 & 3.26 & 4.25 & 4.19 \\
\hline $\begin{array}{l}\text { Mineral and vitamin starter } / \mathrm{g} \\
6,000 / 14,000, \mathrm{Cu} 4000 / 2400, \mathrm{C} \\
\text { butylated hydroxyanisole, buty } \\
\text { 3; mg: } 14,400 / 10,000 \text { vit. E, } 800 \\
\text { antothenic acid, } 12,000 / 6000 \text { nic }\end{array}$ & er pre & ontaine & $1 \mathrm{~kg} ; \mathrm{r}$ & oline & $\begin{array}{l}\text { de } 140, \\
\text { Se } 40 / 5 \\
\text { A, } 100,0 \\
800 \text { vit. }\end{array}$ & 0,000 \\
\hline
\end{tabular}

During the growth experiment, the birds' body weight was controlled on day 1, 21 and 42 along with the intake of feed in respective rearing periods. The results were used to calculate weight gain and feed conversion (FCR) per weight gain unit.

On the 42nd day of the birds' life, ten birds (five males and five females) with a body weight representative of a specific group and sex were selected from each group and slaughtered. Next, the carcasses were cooled over $24 \mathrm{~h}$ at a temperature of $4{ }^{\circ} \mathrm{C}$. To calculate the dressing percentage, the weight of cooled carcasses was determined and they were subject to simplified dissection analysis using a procedure described by Ziołecki and Doruchowski [51]. During dissection, samples of breast and leg muscles were taken for evaluating their physico-chemical and organoleptic characteristics. 


\subsection{Chemical Composition Evaluation of Milk Thistle and Muscles}

The samples for analysis were collected according to applicable requirements [52]. The dry matter, total ash, crude protein, and crude fat contents were described by the AOAC [53] according method number: dry matter (930.15), total ash (942.05), crude protein (990.03), crude fat (991.36) and crude fiber (978.10). The gross energy of milk thistle was determined using an Oxygen Bomb Calorimeter [54]. The number of nitrogen-free extractives (NFE) was calculated from the formula:

$$
\mathrm{NFE}=\text { dry matter }-(\text { crude protein }+ \text { total ash }+ \text { crude fat }+ \text { crude fiber })
$$

The fatty acid profile in milk thistle and in muscles was determined by gas chromatography [55]. Fatty acid analysis was made with gas chromatography (GC) using gas chromatograph (GCMS-QP210 Ultra, Shimadzu, Kyoto, Japan) with capillary column and flame-ionization detection and helium as the carrier gas. The initial oven temperature was $140{ }^{\circ} \mathrm{C}$ for $1 \mathrm{~min}$, thereafter increased by $20^{\circ} \mathrm{C} / \mathrm{min}$ to $200{ }^{\circ} \mathrm{C}$ and held for $20 \mathrm{~min}$ and increased by $5{ }^{\circ} \mathrm{C} / \mathrm{min}$ to $220^{\circ} \mathrm{C}$ held for $25 \mathrm{~min}$. The injector was heated to $250{ }^{\circ} \mathrm{C}$ and the detector to $270{ }^{\circ} \mathrm{C}$. FAME standards (Supelco 37 Component FAME Mix) were used to identify the fatty acids present in the samples. Based on the percentage ( $\%$ of the total) of fatty acids, we calculated the atherogenic (AI) and thrombogenic (TI) indexes, as well as the hypocholesterolemic-to-hypercholesterolemic fatty acids ratio $(\mathrm{HH})$ according to Ulbricht and Southgate [56] and Santos-Silva et al. [57]:

$$
\mathrm{AI}=(\mathrm{C} 12: 0+4 \times \mathrm{C} 14: 0+\mathrm{C} 16: 0) /[\Sigma \mathrm{MUFA}+\Sigma(\mathrm{n}-6)+\Sigma(\mathrm{n}-3)]
$$

$$
\mathrm{TI}=(\mathrm{C} 14: 0+\mathrm{C} 16: 0+\mathrm{C} 18: 0) /[0.5 \times \Sigma \text { MUFA }+0.5 \times \Sigma(\mathrm{n}-6)+3 \times \Sigma(\mathrm{n}-3)+\Sigma(\mathrm{n}-3) / \Sigma(\mathrm{n}-6)]
$$

$\mathrm{HH}=[(\mathrm{C} 18: 1 \mathrm{n}-9+\mathrm{C} 18: 2 \mathrm{n}-6+\mathrm{C} 20: 4 \mathrm{n}-6+\mathrm{C} 18: 3 n-3+\mathrm{C} 20: 5 n-3+\mathrm{C} 22: 5 \mathrm{n}-3+\mathrm{C} 22: 6 \mathrm{n}-3) /(\mathrm{C} 14: 0+\mathrm{C} 16: 0)]$

\subsection{Physical Properties Evaluation of Muscles}

The concentration of hydrogen ions $\left(\mathrm{pH}_{15}\right.$ and $\left.\mathrm{pH}_{24}\right)$ in pectoralis maior and iliotibialis muscles was measured using a Testo $205 \mathrm{pH}$-meter with a dagger electrode. Fifteen minutes after the slaughter and after over $24 \mathrm{~h}$ of cooling the reaction $\left(\mathrm{pH}_{15}\right.$ and $\left.\mathrm{pH}_{24}\right)$ was measured in muscles.

Water absorption expressed as water holding capacity (WHC) was determined by Grau and Hamm's filter-paper press method described by Jurczak [58] based on the surface of meat juice on the filter-paper.

The color of breast muscles was determined using a Minolta Chroma Metters CR 300 (Konica Minolta Osaka, Japan) instrument according to the $\mathrm{L}, \mathrm{a}^{*}, \mathrm{~b}^{*}$ system [59]. Two illuminant/observer combinations were applied, i.e., illuminant $C$ (average day light) and standard observer $2^{\circ}$ as well as illuminant D65 (day light) and standard observer $10^{\circ}$, recommended for measurements of meat color [60]. In the used measuring system $\mathrm{L}$ denotes psychometric color saturation that is a spatial vector. On the other hand, $\mathrm{a}^{*}$ and $\mathrm{b}^{*}$ are trichromatic coordinates, where $\mathrm{a}^{*}$ as a positive value corresponds to red, and as a negative value - green; in turn, positive $b^{*}$ corresponds to yellow, and negative $b^{*}$ blue. The color parameters $a^{*}$ and $b^{*}$ were used to calculate chroma $(C)$ and hue $(H)$ with formulas used by [61].

\subsection{Organoleptic Properties of Muscles}

The organoleptic properties of breast and thigh muscles were evaluated on a five-point scale after cooking in a $0.8 \% \mathrm{NaCl}$ solution up to a temperature of $80{ }^{\circ} \mathrm{C}$ in the geometric center of the sample. The meat to water ratio was 1:2. The flavor of muscles in terms of palatability, flavor, juiciness and tenderness was evaluated by a group of eight trained people $[62,63]$. 


\subsection{Statistical Analysis}

The results were elaborated by statistical methods using one-way analysis of variance, according to the following mathematical model:

$$
\mathrm{Y}_{\mathrm{ik}}=\mu+\mathrm{a}_{\mathrm{i}}+\mathrm{e}_{\mathrm{ik}}
$$

where:

$\mathrm{Y}_{\mathrm{ik}}$ - trait level,

$\mu$-total mean,

$\mathrm{a}_{\mathrm{i}}$-effect of treatment,

$\mathrm{e}_{\mathrm{ik}}$ - error.

The significance of differences between mean values was verified using Tukey test at the significance level $\alpha \leq 0.05$. The results were elaborated using STATISTICA PL 13.1 software [64].

\section{Results}

The evaluated seeds of milk thistle (Silybum marianum [L.] Gaertn.) contained $219 \mathrm{~g} / \mathrm{kg}$ of total protein and $238 \mathrm{~g} / \mathrm{kg}$ of crude fat with an advantageous fatty acid composition (Table 2).

Table 2. Basic nutrients, energy value and fatty acids profile of milk thistle seeds.

\begin{tabular}{|c|c|}
\hline Specification & Composition $(n=3)$ \\
\hline \multicolumn{2}{|l|}{ Basical nutrients $(\mathrm{g} / \mathrm{kg})$} \\
\hline Dry matter & 886 \\
\hline Crude ash & 31.5 \\
\hline Crude protein & 219 \\
\hline Crude fat & 238 \\
\hline Crude fiber & 41.3 \\
\hline $\mathrm{N}$-free extractives & 356.2 \\
\hline Gross energy value (kcal/kg) & 4145 \\
\hline \multicolumn{2}{|l|}{ Fatty acids (\% total FA) } \\
\hline $\mathrm{C} 12: 0$ & 0.010 \\
\hline C14:0 & 0.110 \\
\hline $\mathrm{C} 16: 0$ & 8.52 \\
\hline C16:1 & 0.090 \\
\hline C18:0 & 4.78 \\
\hline C18:1 & 23.59 \\
\hline $\mathrm{C} 18: 2$ & 54.64 \\
\hline C18:3 & 0.160 \\
\hline C20:0 & 3.25 \\
\hline C20:1 & 0.920 \\
\hline $\mathrm{C} 22: 0$ & 2.41 \\
\hline $\mathrm{C} 22: 4$ & 0.190 \\
\hline others & 1.33 \\
\hline SFA & 19.08 \\
\hline UFA & 79.59 \\
\hline MUFA & 24.60 \\
\hline PUFA & 54.99 \\
\hline DFA (UFA + C18:0) & 84.37 \\
\hline OFA (C14:0 + C16:0) & 8.63 \\
\hline $\mathrm{AI}$ & 0.110 \\
\hline TI & 0.330 \\
\hline $\mathrm{h} / \mathrm{H}$ & 9.11 \\
\hline
\end{tabular}


The seeds contained only $19.08 \%$ of SFA (saturated fatty acids). The content of MUFA (monounsaturated fatty acids) exceeded $24.60 \%$ and PUFA (polyunsaturated fatty acids) were predominant-54.99\%. Among all monounsaturated acids, milk thistle contained the largest share of oleic acid-23.59\%, and the polyunsaturated acids profile was dominated by linoleic acid- $54.64 \%$. As a result, nearly $85 \%$ of total fatty acids (FA) in milk thistle seeds were neutral and hypocholesterolemic acids (DFA).

The inclusion of milk thistle seeds in starter/grower diets in the amount $2 / 3 \%$ (MT23 group) significantly (by more than 3\%) increased the body weight of broilers on the 42nd day of rearing in comparison to group C (Table 3).

Table 3. Rearing results of broiler chickens.

\begin{tabular}{|c|c|c|c|c|c|}
\hline \multirow{2}{*}{ Indicators } & \multicolumn{3}{|c|}{ Groups } & \multirow{2}{*}{ SEM } & \multirow{2}{*}{$p$-Value } \\
\hline & $\mathrm{C}$ & MT02 & MT23 & & \\
\hline \multicolumn{6}{|c|}{ Body weight (g) } \\
\hline $1 \mathrm{~d}$ & 39.8 & 39.3 & 39.2 & 0.083 & 0.051 \\
\hline $21 \mathrm{~d}$ & 667 & 666 & 674 & 3.56 & 0.680 \\
\hline $42 \mathrm{~d}$ & $2306^{b}$ & $2377^{a b}$ & $2389^{a}$ & 14.75 & $<0.05$ \\
\hline \multicolumn{6}{|c|}{ Body weight gain (g) } \\
\hline $1-21 \mathrm{~d}$ & 627 & 627 & 635 & 3.59 & 0.657 \\
\hline $22-42 \mathrm{~d}$ & 1639 & 1711 & 1715 & 15.10 & 0.056 \\
\hline $1-42 \mathrm{~d}$ & $2267^{b}$ & $2338^{a b}$ & $2350^{a}$ & 14.76 & $<0.05$ \\
\hline \multicolumn{6}{|c|}{ Feed conversion ratio $(\mathrm{kg})$} \\
\hline $1-21 \mathrm{~d}$ & $1.61^{\mathrm{a}}$ & $1.57^{\mathrm{a}}$ & $1.51^{\mathrm{b}}$ & 0.013 & $<0.05$ \\
\hline $22-42 \mathrm{~d}$ & $1.85^{\mathrm{a}}$ & $1.79^{b}$ & $1.71^{\mathrm{c}}$ & 0.016 & $<0.05$ \\
\hline $1-42 d$ & $1.74^{\mathrm{a}}$ & $1.69^{b}$ & $1.61^{\mathrm{c}}$ & 0.015 & $<0.05$ \\
\hline
\end{tabular}

C-control, MT02-milk thistle (0\%/2\%-starter/grower), MT23-milk thistle (2\%/3\%-starter/grower), SEMstandard error of mean, $n=5$, chickens survivability $=100 \%$, abc-means with different superscripts within a row are significantly different at $p \leq 0.05$.

Milk thistle in starter diets (group MT23) significantly decreased feed conversion in comparison to other groups. In the second rearing period and throughout the entire rearing period-chickens fed diets with milk thistle showed more efficient $(p \leq 0.05)$ conversion of feed. Differences in FCR between groups MT02 and MT23 and group C were 3\% and 7\%, respectively, throughout the rearing period. The type of feed rations used did not affect the post-slaughter performance, except the share of drumstick muscles (Table 4).

Table 4. Slaughter analysis of broiler chickens.

\begin{tabular}{cccccc}
\hline \multirow{2}{*}{ Parameters } & \multicolumn{3}{c}{ Group } & \multirow{2}{*}{ SEM } & $p$-Value \\
\cline { 2 - 4 } & C & MT02 & MT23 & & \\
\hline Body weight before slaughter (g) & 2330 & 2392 & 2370 & 28.4 & 0.069 \\
Cold carcasses weight (g) & 1839 & 1875 & 1856 & 28.2 & 0.882 \\
Dressing percentage (\%) & 78.9 & 78.4 & 78.2 & 0.532 & 0.888 \\
Muscles total (\%) & 51.4 & 51.4 & 50.1 & 0.472 & 0.466 \\
breast & 30.0 & 29.9 & 29.7 & 0.436 & 0.975 \\
thigh & 12.7 & 12.4 & 12.3 & 0.166 & 0.543 \\
drumstick & 8.74 ab & $9.03^{\mathrm{a}}$ & $8.13 \mathrm{~b}$ & 0.139 & $<0.05$ \\
Abdominal fat (\%) & 0.62 & 0.79 & 0.82 & 0.040 & 0.098 \\
Skin with subcutaneous fat (\%) & 7.38 & 7.31 & 7.68 & 0.167 & 0.659 \\
Giblets total share in body weight & 3.30 & 3.20 & 3.36 & 0.029 & 0.299 \\
before slaughter (\%) & & & & \\
heart & 0.50 & 0.48 & 0.46 & 0.010 & 0.305 \\
liver & 1.79 & 1.61 & 1.71 & 0.036 & 0.124 \\
stomach & 1.01 & 1.11 & 1.18 & 0.030 & 0.056
\end{tabular}

C-control, MT02-milk thistle (0\%/2\%-starter/grower), MT23-milk thistle (2\%/3\%-starter/grower), SEMstandard error of mean, $n=10$, ab-means with different superscripts within a row are significantly different at $p \leq 0.05$. 
The presence of ground seeds of Silybum marianum in starter and grower diets (MT02 group) significantly increased the share of drumstick muscles in cold carcass compared to muscles of birds from MT23 group (9.03\% vs. $8.13 \%$ ).

The nutrition used significantly affected the content of crude ash in breast muscles and the level of crude fat in leg muscles (Table 5).

Table 5. Basic nutrients ( $\mathrm{g} / 100 \mathrm{~g})$ of muscles.

\begin{tabular}{cccccc}
\hline Specification & \multicolumn{3}{c}{ Group } & \multirow{2}{*}{ SEM } & $p$-Value \\
\cline { 2 - 4 } & C & MT02 & MT23 & & \\
\hline Breast muscles & & & & \\
Dry matter & 25.4 & 25.0 & 25.0 & 0.134 & 0.292 \\
Crude ash & $1.17^{\mathrm{a}}$ & $1.12^{\mathrm{b}}$ & $1.16^{\mathrm{ab}}$ & 0.007 & $<0.05$ \\
Crude protein & 22.3 & 22.2 & 22.0 & 0.094 & 0.576 \\
Crude fat & 1.13 & 1.10 & 0.92 & 0.639 & 0.399 \\
Leg muscles & & & & \\
Dry matter & 24.5 & 24.5 & 24.1 & 0.212 & 0.726 \\
Crude ash & 1.06 & 1.07 & 1.07 & 0.004 & 0.405 \\
Crude protein & 18.8 & 19.4 & 19.5 & 0.144 & 0.102 \\
Crude fat & $4.01^{\mathrm{a}}$ & $3.43^{\mathrm{b}}$ & $3.25^{\mathrm{b}}$ & 0.120 & $<0.05$ \\
\hline
\end{tabular}

C-control, MT02-milk thistle (0\%/2\%—-starter/grower), MT23-milk thistle (2\%/3\%-starter/grower), SEMstandard error of mean, $n=5\left(n=\sigma^{2}+q\right)$, ab-means with different superscripts within a row are significantly different at $p \leq 0.05$.

The breast muscles of birds from group MT02 contained significantly less crude ash than the muscles of birds from group C. Milk thistle seeds in chicken diets (groups MT02 and MT23) contributed to decreasing $(p<0.05)$ the content of crude fat in leg muscles.

Table 6 describes the composition and share of fatty acids in the lipid fraction of breast and leg muscles.

Table 6. Fatty acids profile (\% total FA) of muscles.

\begin{tabular}{|c|c|c|c|c|c|}
\hline \multirow{2}{*}{ Fatty Acids } & \multicolumn{3}{|c|}{ Group } & \multirow{2}{*}{ SEM } & \multirow{2}{*}{$p$-Value } \\
\hline & $\mathrm{C}$ & MT02 & MT23 & & \\
\hline \multicolumn{6}{|l|}{ Breast muscles } \\
\hline C14:0 & 0.110 & 0.110 & 0.100 & 0.004 & 0.239 \\
\hline C16:0 & 22.19 & 21.71 & 21.45 & 0.231 & 0.285 \\
\hline C18:0 & 5.92 & 5.91 & 5.82 & 0.115 & 0.941 \\
\hline C18:1 & 34.33 & 33.84 & 32.19 & 0.433 & 0.065 \\
\hline$C 18: 2 n-6$ & $32.59^{b}$ & $33.87^{a b}$ & $36.00^{\mathrm{a}}$ & 0.561 & $<0.05$ \\
\hline$C 18: 3 n-3$ & $1.05^{b}$ & $1.25^{\mathrm{ab}}$ & $1.49^{\mathrm{a}}$ & 0.080 & $<0.05$ \\
\hline C20:0 & 0.100 & 0.100 & 0.090 & 0.005 & 0.587 \\
\hline C20:1 & $0.070^{b}$ & $0.110^{\mathrm{a}}$ & $0.050^{\mathrm{b}}$ & 0.010 & $<0.05$ \\
\hline C20:2 & 0.080 & 0.080 & 0.070 & 0.004 & 0.743 \\
\hline$C 20: 3 n-3$ & 0.050 & 0.050 & 0.050 & 0.001 & 0.913 \\
\hline C20:4 n-6 & $0.600^{\mathrm{a}}$ & $0.450^{b}$ & $0.450^{b}$ & 0.037 & $<0.05$ \\
\hline SFA & 28.45 & 27.99 & 27.62 & 0.278 & 0.382 \\
\hline UFA & 71.46 & 71.89 & 72.25 & 0.276 & 0.402 \\
\hline MUFA & $37.09^{\mathrm{a}}$ & $36.19^{a b}$ & $34.19^{b}$ & 0.528 & $<0.05$ \\
\hline PUFA & $34.37^{b}$ & $35.70 \mathrm{ab}$ & $38.06^{\mathrm{a}}$ & 0.619 & $<0.05$ \\
\hline DFA (UFA + C18:0) & 77.38 & 77.80 & 78.07 & 0.227 & 0.317 \\
\hline OFA (C14:0 + C16:0) & 22.30 & 21.82 & 21.55 & 0.234 & 0.278 \\
\hline$n-6: n-3$ & $30.17^{\mathrm{a}}$ & $26.40^{a b}$ & $23.67^{b}$ & 0.600 & $<0.05$ \\
\hline $\mathrm{AI}$ & 0.320 & 0.311 & 0.302 & 0.006 & 0.387 \\
\hline TI & 0.731 & 0.712 & 0.682 & 0.018 & 0.849 \\
\hline $\mathrm{h} / \mathrm{H}$ & 3.08 & 3.18 & 3.26 & 0.108 & 0.989 \\
\hline
\end{tabular}


Table 6. Cont.

\begin{tabular}{|c|c|c|c|c|c|}
\hline \multirow{2}{*}{ Fatty Acids } & \multicolumn{3}{|c|}{ Group } & \multirow{2}{*}{ SEM } & \multirow{2}{*}{$p$-Value } \\
\hline & C & MT02 & MT23 & & \\
\hline \multicolumn{6}{|l|}{ Leg muscles } \\
\hline C14:0 & 0.110 & 0.120 & 0.110 & 0.003 & 0.268 \\
\hline C16:0 & 21.41 & 21.66 & 21.24 & 0.091 & 0.156 \\
\hline C18:0 & $4.72^{b}$ & $4.94^{\mathrm{b}}$ & $5.69^{\mathrm{a}}$ & 0.140 & $<0.05$ \\
\hline C18:1 & $35.46^{\mathrm{a}}$ & $34.60^{\mathrm{a}}$ & $32.05^{b}$ & 0.521 & $<0.05$ \\
\hline$C 18: 2 n-6$ & $32.83^{b}$ & $33.62^{a b}$ & $35.63^{a}$ & 0.476 & $<0.05$ \\
\hline$C 18: 3 n-3$ & 1.65 & 1.42 & 1.61 & 0.054 & 0.174 \\
\hline C20:0 & $0.070^{\mathrm{b}}$ & $0.080^{\mathrm{ab}}$ & $0.130^{\mathrm{a}}$ & 0.009 & $<0.05$ \\
\hline C20:1 & $0.100^{\mathrm{a}}$ & $0.060^{\mathrm{b}}$ & $0.040^{\mathrm{b}}$ & 0.008 & $<0.05$ \\
\hline C20:2 & $0.030^{b}$ & $0.030^{b}$ & $0.060^{\mathrm{a}}$ & 0.004 & $<0.05$ \\
\hline$C 20: 3 n-3$ & 0.030 & 0.020 & 0.020 & 0.002 & 0.113 \\
\hline$C 20: 4 n-6$ & $0.320^{\mathrm{a}}$ & $0.170^{\mathrm{b}}$ & $0.310^{\mathrm{a}}$ & 0.027 & $<0.05$ \\
\hline SFA & $26.40^{b}$ & $26.94^{\mathrm{ab}}$ & $27.35^{\mathrm{a}}$ & 0.161 & $<0.05$ \\
\hline UFA & $73.45^{\mathrm{a}}$ & $72.94^{\mathrm{ab}}$ & $72.46^{\mathrm{b}}$ & 0.165 & $<0.05$ \\
\hline MUFA & $38.59^{a}$ & $37.68^{a}$ & $34.83^{b}$ & 0.577 & $<0.05$ \\
\hline PUFA & $34.86^{b}$ & $35.26^{a b}$ & $37.63^{a}$ & 0.491 & $<0.05$ \\
\hline DFA (UFA + C18:0) & 78.17 & 77.88 & 78.15 & 0.083 & 0.287 \\
\hline OFA (C14:0 + C16:0) & 21.52 & 21.78 & 21.35 & 0.093 & 0.152 \\
\hline$n-6: n-3$ & 19.73 & 23.46 & 22.05 & 0.083 & 0.150 \\
\hline AI & 0.301 & 0.300 & 0.300 & 0.006 & 0.365 \\
\hline TI & 0.642 & 0.670 & 0.671 & 0.012 & 0.984 \\
\hline $\mathrm{h} / \mathrm{H}$ & 3.27 & 3.21 & 3.26 & 0.905 & 0.877 \\
\hline
\end{tabular}

C-control, MT02-milk thistle (0\%/2\%—-starter/grower), MT23-milk thistle (2\%/3\%-starter/grower), SEM-standard error of mean, $n=5$, ab-means with different superscripts within a row are significantly different at $p \leq 0.05$, SFA-saturated fatty acids, UFA- unsaturated fatty acids, MUFAmonounsaturated fatty acids, PUFA-polyunsaturated fatty acids, DFA-neutral and hypocholesterolemic fatty acids, OFA - hypercholesterolemic fatty acids, AI—atherogenicity index, TI-thrombogenicity index, h/Hhypocholesterolaemic/Hypercholesterolaemic ratio.

Feeding chickens with feed rations containing 2\% (starter) and 3\% (grower) of Silybum marianum significantly increased the share of stearic acid $\mathrm{C}_{18: 0}$ (classified as neutral and hypocholesterolemic acid) in leg muscles only. Milk thistle introduced into chicken diets increased the content of linoleic acid $\left(\mathrm{C}_{18: 2}\right)$ in both evaluated muscle types, but a higher content of this acid was found in the muscles of chickens from group MT23 in comparison to the control group. Breast muscles of birds receiving feed rations with milk thistle in both rearing periods (MT23 group) contained by about $42 \%$ more linoleic acid than in group C $(p<0.05)$. A high $(p<0.05)$ content of PUFA was determined in the breast $(38.06 \%)$ and leg $(37.63 \%)$ muscles of chicken receiving feed rations containing ground seeds of Silybum marianum throughout the birds' rearing period in comparison to group C. In addition, the breast muscles of birds from group MT23 featured a lower $(p<0.05)$ ratio of n-6:n-3 fatty acids in comparison to chickens fed rations without the phytobiotic.

The introduction of Silybum marianum into chicken diets did not affect the evaluated physical properties ( $\mathrm{pH}$, color, WHC) of thigh muscles, but it changed the color and WHC of breast muscles (Table 7).

Breast muscles of chickens from group MT02-fed with rations containing the evaluated phytobiotic at the grower stage only-were darker $(p<0.05)$. In addition, the use of milk thistle in the diets of birds intensified meat color toward red $\left(\mathrm{a}^{*}\right)$ and increased chroma (C) of breast muscles compared to the $\mathrm{C}$ group. The water holding capacity (WHC) was lower $(p<0.05)$ in the breast muscles of chickens receiving diets containing Silybum marianum. 
Table 7. Physical parameters of muscles.

\begin{tabular}{|c|c|c|c|c|c|}
\hline \multirow{2}{*}{ Parameters } & \multicolumn{3}{|c|}{ Group } & \multirow{2}{*}{ SEM } & \multirow{2}{*}{$p$-Value } \\
\hline & $\mathrm{C}$ & MT02 & MT23 & & \\
\hline \multicolumn{6}{|l|}{ Breast muscles } \\
\hline $\mathrm{pH}_{15}$ & 6.27 & 6.17 & 6.30 & 0.315 & 0.218 \\
\hline $\mathrm{pH}_{24}$ & 5.60 & 5.92 & 5.85 & 0.060 & 0.058 \\
\hline $\mathrm{L}^{*}$ & $53.4^{\mathrm{a}}$ & $49.4^{b}$ & $50.8^{a b}$ & 0.589 & $<0.05$ \\
\hline$a^{*}$ & $2.90^{b}$ & $5.17^{\mathrm{a}}$ & $4.46^{\mathrm{a}}$ & 0.284 & $<0.05$ \\
\hline $\mathrm{b}^{*}$ & 0.810 & 0.790 & 1.19 & 0.168 & 0.579 \\
\hline $\mathrm{C}=\left[\left(\mathrm{a}^{*}\right)^{2}+\left(\mathrm{b}^{*}\right)^{2}\right]^{0.5}$ & $3.08^{b}$ & $5.29^{a}$ & $4.71^{\mathrm{a}}$ & 0.280 & $<0.05$ \\
\hline $\mathrm{H}=\log \left(\mathrm{b}^{*} / \mathrm{a}^{*}\right)$ & 0.290 & 0.140 & 0.300 & 0.046 & 0.327 \\
\hline WHC (\%) & $7.46^{\mathrm{b}}$ & $11.0^{\mathrm{a}}$ & $12.7^{\mathrm{a}}$ & 0.970 & $<0.05$ \\
\hline \multicolumn{6}{|l|}{ Thigh muscles } \\
\hline $\mathrm{pH}_{15}$ & 6.02 & 6.20 & 6.05 & 0.038 & 0.114 \\
\hline $\mathrm{pH}_{24}$ & 6.00 & 5.93 & 5.98 & 0.033 & 0.659 \\
\hline $\mathrm{L}^{*}$ & 50.7 & 51.5 & 53.2 & 0.583 & 0.190 \\
\hline$a^{*}$ & 3.34 & 2.64 & 2.72 & 0.290 & 0.591 \\
\hline $\mathrm{b}^{*}$ & 0.860 & 0.390 & 0.510 & 0.248 & 0.740 \\
\hline $\mathrm{C}=\left[\left(\mathrm{a}^{*}\right)^{2}+\left(\mathrm{b}^{*}\right)^{2}\right]^{0.5}$ & 3.80 & 2.99 & 2.86 & 0.278 & 0.342 \\
\hline $\mathrm{H}=\log \left(\mathrm{b}^{*} / \mathrm{a}^{*}\right)$ & 0.320 & 0.135 & 0.184 & 0.106 & 0.773 \\
\hline WHC (\%) & 5.50 & 5.56 & 6.97 & 0.637 & 0.644 \\
\hline
\end{tabular}

C-control, MT02-milk thistle (0\%/2\%—-starter/grower), MT23-milk thistle (2\%/3\%-starter/grower), SEMstandard error of mean, $n=10$, ab-means with different superscripts within a row are significantly different at $p \leq 0.05, \mathrm{~L}^{*}$ - lightness, $\mathrm{a}^{*}$-redness, $\mathrm{b}^{*}$-yellowness, C—chroma, $\mathrm{H}$-hue, WHC — water holding capacity.

Adding ground seeds of milk thistle both in starter diets $(20 \mathrm{~g} / \mathrm{kg})$ and grower diets $(30 \mathrm{~g} / \mathrm{kg})$ and only in grower diets $(20 \mathrm{~g} / \mathrm{kg})$ had a significant $(p<0.05)$ impact on the evaluated taste characteristics (flavor, tenderness, palatability, juiciness) of breast and thigh muscles, except on juiciness in breast muscles $(p>0.05)$ (Figures 1 and 2 ).

Breast and thigh muscles of chickens fed with rations containing milk thistle in both rearing periods (group MT23) scored the highest.

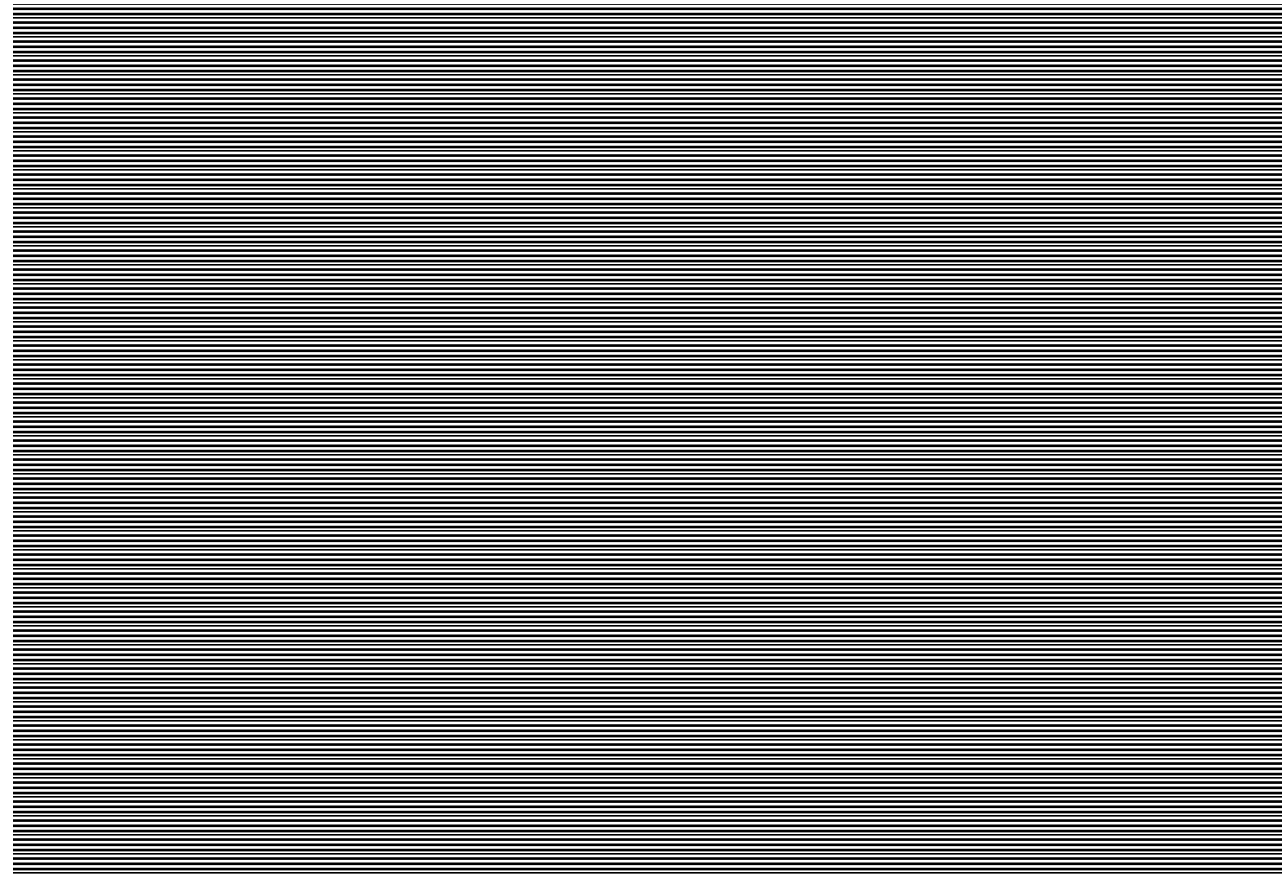

Figure 1. Sensory evaluation of breast muscles (point). C—control, MT02-milk thistle $(0 \% / 2 \%-$ starter/grower), MT23-milk thistle (2\%/3\%—starter/grower), SEM—standard error of mean, $n=8$, $\mathrm{a}, \mathrm{b}-$ means with different superscripts within a row are significantly different at $p \leq 0.05$. 


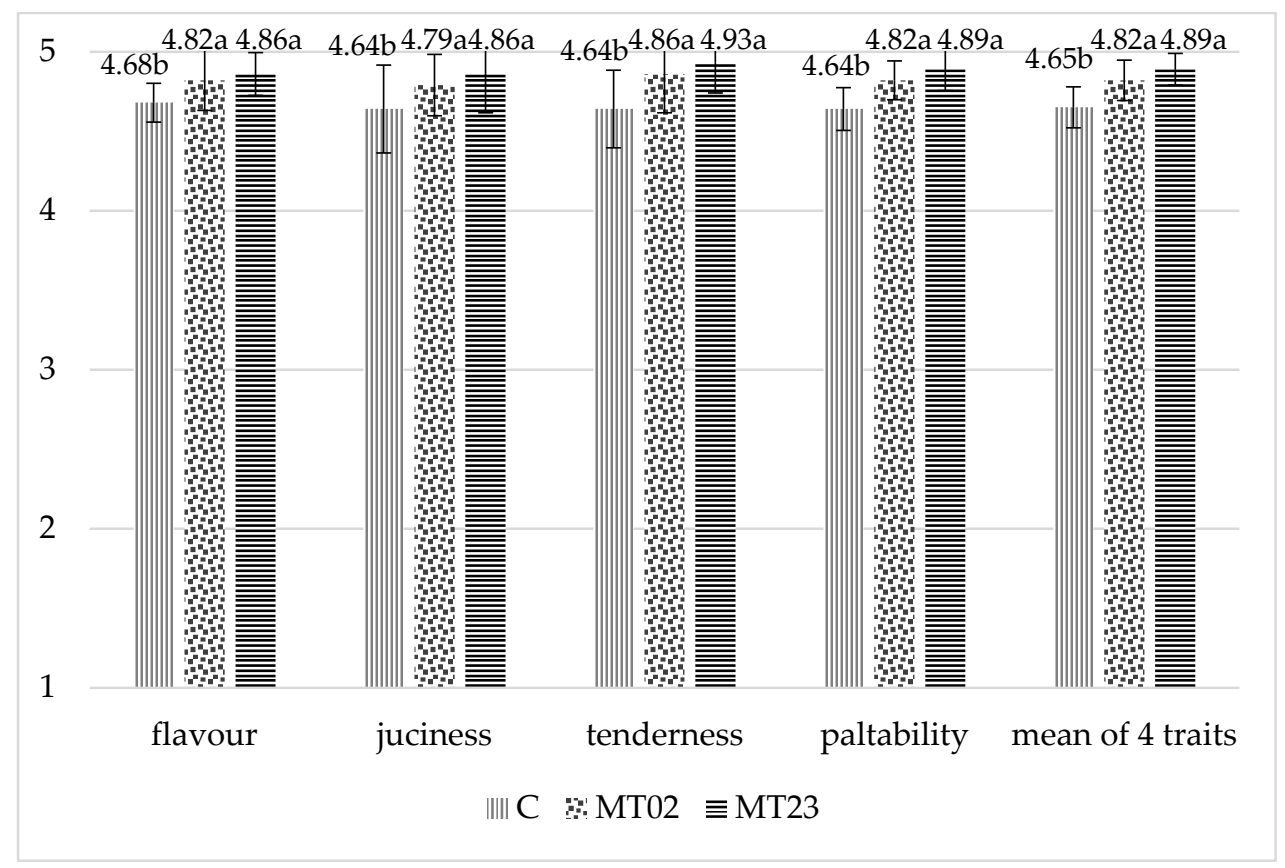

Figure 2. Sensory evaluation of thigh muscles (point). C-control, MT02-milk thistle $(0 \% / 2 \%-$ starter/grower), MT23-milk thistle (2\%/3\%—starter/grower), SEM-standard error of mean, $n=8$, $\mathrm{a}, \mathrm{b}-$ means with different superscripts within a row are significantly different at $p \leq 0.05$.

\section{Discussion}

The content of total protein in the evaluated seeds of milk thistle (Silybum marianum [L.] Gaertn.) ranged from 161 to $250 \mathrm{~g} / \mathrm{kg}$ as reported by many researchers $[21,22,28,65]$. In turn, a higher content of protein in milk thistle seeds (up to $30.09 \%$ ), depending on the variety and origin, was found by Aziz et al. [24]. In the opinion of Grela et al. [21] and Aziz et al. [24] milk thistle seeds are not only a source of protein but also energy, which is corroborated by the level (up to $24.8 \%$ ) of crude fat determining the energy value of the raw material. A lower (17.5-21.6\%) content of fat in milk thistle seeds was demonstrated by Růžičková et al. [66], and a higher content (26.05-30.5\%) of this component was found in the experiments by $[25,26]$. According to $[25,26,67,68]$, the content of crude fat in milk thistle seeds depends on many factors such as: agricultural engineering, the environment, variety, and year of harvest. The determined content of crude fiber in the evaluated seeds amounted to $41.3 \mathrm{~g} / \mathrm{kg}$, which was below the range of $45.6-54.6 \mathrm{~g} / \mathrm{kg}$ reported by Grela et al. [23].

An analysis of the fatty acids profile of Silybum marianum seeds showed a high level of unsaturated fatty acids, including linoleic acid (54.64\% FA) and oleic acid (23.59\% FA). Similar content of fatty acids was measured by Garaev et al. [69], Růžičková et al. [66] and Harrabi et al. [26], who in the evaluated samples of milk thistle seeds determined $50.58-66.4 \%$ of linoleic acid, $16.26-25.44 \%$ of oleic acid, $7.24-9.20 \%$ of palmitic acid and $3.56-5.92 \%$ of stearic acid. The above-mentioned higher shares of linoleic acid $(64.4 \%)$ and oleic acid (26.38\%) in the lipids of Silybum marianum seeds were found by Khan et al. [25], whereas a lower $(45.36 \%$ and $39 \%$ ) share of linoleic acid but a higher $(31.58 \%$ and $36 \%)$ share of oleic acid was determined by Hasanloo et al. [70] and Majidi et al. [27], respectively.

Grela at al. [23] demonstrated a share of MUFA ( $24.98 \%$ vs. $24.60 \%$ FA) and that of PUFA (55.56\% vs. $54.99 \%$ FA), which is similar to the level determined by the present authors. Wierzbowska et al. [68] found that the share of polyunsaturated fatty acids (PUFA), including linoleic acid, was lower than in own studies. In turn, Kralik et al. [47] noted a higher content $(63.11 \%)$ of PUFA in milk thistle seeds. Big differences in the share of respective fatty acids in the seeds of Silybum marianum depending on the year of harvest were revealed by Sadowska et al. [28]. 
A positive impact on weight gain and feed conversion after introducing milk thistle into the feed rations for broiler chickens was observed by Tedesco et al. [31] and Muhammad et al. [42]. Mojahedtalab et al. [45] noted a linear improvement in body weight gain with a decreasing conversion of feed and an increasing content of silymarin in feed rations for broiler chickens. Similarly, Ahmad et al. [20] showed that overall body weight and feed conversion ratio were significantly $(p<0.5)$ higher for group MT-15 (rations $15 \mathrm{~g} / \mathrm{kg}$ of milk thistle) compared with other experimental groups. In turn, Gharahveysi [44] found that the feed intake and body weight of chickens decreased as the share of milk thistle in their diet increased. Feed intake in diets containing $0.3 \%$ or $3 \%$ of Silybum marianum was 3.440 and $3.407 \mathrm{~kg}$, respectively, and body weight was 1.810 and $1.793 \mathrm{~kg}$, respectively. Other authors who demonstrated a reduction in the productivity of broiler chickens after including Silybum marianum in their diets were Suchý et al. [41], Kalantar et al. [71] and Št'astník et al. [43]. Suchý et al. [41] found that the use of $0.2 \%$ or $1 \%$ milk thistle seed expeller in feed rations for Ross 308 broilers resulted in decreasing weight gain and impaired feed conversion. Similarly, Kalantar et al. [71] showed that 0.5\% Silybum marianum introduced into feed rations for broiler chickens decreased (by about 10\%) daily weight gain and increased (by $4.5 \%$ ) the feed conversion rate (FCR) in comparison to birds fed diets without milk thistle. The weight gain of chickens decreased after using $5 \%$ or $15 \%$ of milk thistle (Silybum marianum) oil cake in feed rations, as noted by Št'astník et al. [43].

A decreased carcass yield after adding Silybum marianum to broiler diets was observed by Schiavone et al. [46] and Št'astník et al. [43]. Št'astník et al. [43] using 5\% or $15 \%$ of milk thistle seeds in feed rations observed a decrease in carcass yield by $3.86 \%$ and $4.22 \%$ of carcass yield compared to control chickens. A linear decrease in carcass yield accompanied by an increase in the share of milk thistle in the diets of birds was also obtained by Schiavone et al. [46]. On the other hand, an increase $(p<0.05)$ in the dressing percentage of chickens after adding Silybum marianum in the amount of $15 \mathrm{~g} / \mathrm{kg}$ of feed rations was observed by Ahmad et al. [20].

In the production of broilers breast muscle weight in relation to carcass weight is of economic significance. Breast muscles account for about $30 \%$ of edible meat in the whole carcass [72], which is corroborated by the results of own studies. The absence of any impact of Silybum marianum in broiler chicken diets on the share of breast muscles in the carcass is consistent with the findings of Št'astník et al. [43] and Rashidi et al. [49]. Rashidi et al. [49] also demonstrated that a share $(0.5 \%, 1 \%, 1.5 \%$ and $2 \%)$ of Silybum marianum in diets had no impact on the share of abdominal fat. A significant decrease in the share of abdominal fat in the carcasses of birds fed with rations containing milk thistle extract $(250 \mathrm{mg} / \mathrm{kg})$ was found by Tavakolinasab et al. [7].

Št'astník et al. [43] reports that broilers receiving feed rations with a higher (15\%) content of milk thistle had a higher (2.69\% vs. $2.3 \%)$ share of liver than those fed with diets free from and containing $5 \%$ of Silybum marianum. Similarly, Tavakolinasab et al. [7] report that introducing milk thistle extract in the amount of $250 \mathrm{mg} / \mathrm{kg}$ of chicken diet leads to an increase (by $0.21 \%$ ) in the share of liver.

Poultry meat available on the market should be of proper quality, perceived by consumers as a collection of many features, including nutritional value as one of the most important characteristics [73-75]. Poultry meat is a source of complete animal protein thataccording to FAO/WHO (Food and Agriculture Organization of the United Nations/World Health Organization) - is equivalent to milk protein. In addition, its energy value is lower $[76,77]$.

The absence of an impact of milk thistle in broiler chicken feed on the total protein content in breast and leg muscles corroborates the results obtained by Št'astník et al. [48]. However, own studies showed a significant reduction in the amount of crude fat contained in the leg muscles of birds receiving feed rations with milk thistle in comparison to the control group. Schiavone et al. [46] studied chemical properties of breast meat and showed that the application of 40 and $80 \mathrm{ppm}$ dried extract of milk thistle fruit in broiler feed $(1.19 \%$ and $1.74 \%$ in fresh weight, respectively) significantly reduced fat content $(2.15 \%)$. 
Thigh fat decreased in birds fed $40 \mathrm{ppm}$ dried Silybum marianum extract (3.81\% live weight) compared to a control group (4.79\% live weight) and birds fed $80 \mathrm{ppm}$ dried SM fruit extract ( $4.22 \%$ live weight). Dry matter, protein and ash content of breast and thigh meat did not significantly differ between the control and dried Silybum marianum extract fed groups. In turn, Grela et al. [21] analyzing the content of crude fat in the longissimus lumborum muscle of fatteners fed with rations containing $3 \%$ or $6 \%$ of milk thistle seeds noted a significant reduction in the content of this ingredient only when the content of milk thistle in the diet was reduced.

Own studies showed an increased share of stearic and linoleic acids in the muscles of chickens receiving feed rations containing milk thistle seeds. In turn, Kralik et al. [47], using feed rations with $3 \%$ of milk thistle oil for slaughter chickens, noted a decreased share of those acids in the breast and leg muscles. On the other hand, Grela et al. [21], having introduced $3 \%$ or $6 \%$ of milk thistle seeds in the diets of fatteners, noted a significant decrease in the share of stearic acid and an increased content of linoleic acid in the longissimus lumborum muscle. The increased share of PUFA in the muscles of birds fed with diets containing Silybum marianum is contrary to the findings of Kralik et al. [47] but consistent with those of Grela et al. [21] in studies involving fatteners. In addition, the values of atherogenicity index (AI), thrombogenicity index (TI) and hypo- and hypercholesterolemic ratio $(\mathrm{h} / \mathrm{H})$ in the breast muscles of chickens receiving experimental feed rations corroborated the tendency noted in the studies by Grela et al. [21].

The studies and experiments carried out by Kralik et al. [47] and Št'astník et al. [48] showed different impacts of diets containing milk thistle on the acidity of broiler chickens meat. The results did not corroborate an impact of the nutrition used on the reaction of breast and leg muscles, while Kralik et al. [47] found a decrease in the initial $\mathrm{pH}$ and an increase in the final $\mathrm{pH}$ of breast muscles after adding $3 \%$ of oil to the diet. In turn, Št'astník et al. [48] noted an increased $\mathrm{pH}$ of breast muscles after adding $5 \%$ or $15 \%$ (of Silybum marianum) to broiler chicken feed rations.

Color is an important attribute taken into account by consumers when buying meat, and an important element of evaluating meat dishes during their consumption [78]. Meat of darker color due to a higher share of oxidized myoglobin, is less desired by consumers [75]. Broiler meat color depends on the genotype and age [79], animal technology conditions, and feeding regime [80]. Numerous studies $[75,81,82]$ showed that the higher the $\mathrm{pH}$ of meat is, the darker its color and vice versa. Extremely high $\mathrm{pH}$ leads to DFD and low to PSE meat defect [83].

The obtained L color values in the evaluated muscles were characteristic of normal muscles, since Van Laack et al. [84] classified breast muscle tissue as normal (CIE $\left.L^{*} \leq 55.0\right)$ and lighter than normal (CIE L* > 60.0). A lighter $\mathrm{L}^{*}$ color (61.25 and 62.58) and the yellow saturation (13.19 and 13.51) of breast muscles immediately after using $5 \%$ and $15 \%$ of Silybum marianum was observed by Št'astník et al. [48]. In turn, red saturation (4.86 and 5.16) corresponded to own results for breast muscles of birds fed with rations containing ground milk thistle seeds. In turn, Kralik et al. [47], having added milk thistle oil to the feed rations, demonstrated a lower (1.66) value for parameter $\mathrm{a}^{*}$ and a higher (12.01) value for parameter $b^{*}$ in the breast muscles compared to the results of own studies.

The WHC results obtained for muscles of chickens fed with rations containing Silybum marianum point to an impairment of the water holding capacity, but Kralik et al. [47] noted a positive impact of milk thistle seeds on drip loss.

In these studies, a positive impact of diets containing milk thistle seeds on the organoleptic (sensory) characteristics of muscles was noted. However, Št'astník et al. [48], having introduced $5 \%$ or $15 \%$ of milk thistle into chicken diets, demonstrated a deteriorated flavor score for both types of muscles, although the difference was confirmed to be statistically significant only in the breast muscles of chickens receiving 5\% Silybum marianum in diets as compared to other groups.

Higher notes for respective sensory characteristics of thigh muscles should be associated with a higher content of fat in comparison to breast muscles. Komprda et al. [85] 
underlined that leg meat contains more fat and flavour substances, and is thus a preferred consumer choice. According to Nowak and Trziszka [73], in selecting meat its palatability and nutritional value are equally important.

\section{Conclusions}

Based on the results of studies, the use of milk thistle seeds in broiler chicken starter/grower diets can be recommended in the amount of $2 / 3 \%$. The introduction of Silybum marianum in both types of feed rations made it possible to obtain the highest body weight at the lowest feed conversion per body weight gain unit, without any influence on muscularity and fattening grade. At the same time, muscles of chickens fed diets containing the phytobiotic featured the healthiest fatty acid profile and good taste characteristics.

Author Contributions: Conceptualization, A.J. and D.P.; methodology, A.J. and A.M.; software, A.M.; validation, A.J.; formal analysis, A.M.; investigation, D.P. and A.J.; resources, A.J. and D.P.; data curation, A.J.; writing—original draft preparation, A.J., D.P. and A.M.; writing—review and editing, A.J. and A.M.; visualization, A.M.; funding acquisition, A.J. All authors have read and agreed to the published version of the manuscript.

Funding: This research was funded by the Ministry of Science and Higher Education of the Poland.

Institutional Review Board Statement: Ethical review and approval were waived for this study, due to the slaughter of birds was carried out in accordance with the applicable rules on the handling of animals at the time of slaughter, including humane treatment. Additionally, the methods used in the meat quality tests were carried out in accordance with the current and commonly used methodology de-scribed in the Material and methods section. Accordingly to directive no. 2010/63/EU the approval of the Ethics Committee was not required.

Data Availability Statement: The data are available on request from the corresponding author.

Conflicts of Interest: The authors declare no conflict of interest.

\section{References}

1. Alçiçek, A.; Bozkurt, M.; Çabuk, M. The effect of mixture of herbal essential oils, an organic acid or a probiotic on broiler performance. S. Afr. J. Anim. Sci. 2004, 34, 217-222.

2. Skomorucha, I.; Sosnówka-Czajka, E. Effect of water supplementation with herbal extracts on broiler chicken welfare. Ann. Anim. Sci. 2013, 13, 849-857. [CrossRef]

3. Radulović, N.S.; Mladenović, M.Z.; Randjelovic, P.J.; Stojanović, N.M.; Dekić, M.S.; Blagojević, P.D. Toxic essential oils. Part IV: The essential oil of Achillea falcata L. as a source of biologically/pharmacologically active trans-sabinyl esters. Food Chem. Toxicol. 2015, 80, 114-129. [CrossRef]

4. Laskowski, S.; Banaszkiewicz, T.; Milczarek, A. Influence of oregano added to diets on performance, selected organs as well as morphometric traits and $\mathrm{pH}$ of digestive tract of broiler chickens. Med. Weter. 2017, 73, 781-785. [CrossRef]

5. Zhang, Z.S.; Wang, S.; Liu, H.; Li, B.Z. Constituents and thermal properties of milk thistle seed oils extracted with three methods. LWT Food Sci. Technol. 2020, 126, 109282. [CrossRef]

6. Hippenstiel, F.; Abdel-Wareth, A.A.A.; Kehraus, S.; Südekum, K.-H. Effect of selected herbs and essential oils, and their active components on feed intake and performance of broilers-A review. Arch. Geflugelkd. 2011, 75, 226-234.

7. Tavakolinasab, F.; Khosravinia, H.; Masouri, B. Effects of Milk Thistle, Artichoke and Olive Extracts in Comparison with Atorvastatin and Gemfibrozil on Liver Function in Broiler Chicken. Poult. Sci. J. 2020, 8, 109-117. [CrossRef]

8. Hashemipour, H.; Kermanshahi, H.; Golian, A.; Veldkamp, T. Effect of thymol and carvacrol feed supplementation on performance, antioxidant enzyme activities, fatty acid composition, digestive enzyme activities, and immune response in broiler chickens. Poult. Sci. 2013, 92, 2059-2069. [CrossRef]

9. Stastnik, O.; Pavlata, L.; Mrkvicova, E. The Milk Thistle Seed Cakes and Hempseed Cakes are Potential Feed for Poultry. Animals 2020, 10, 1384. [CrossRef]

10. Nowak, A.; Florkowska, K.; Zielonka-Brzezicka, J.; Duchnik, W.; Muzykiewicz, A.; Klimowicz, A. The effects of extraction techniques on the antioxidant potential of extracts of different parts of milk thistle (Silybum marianum L.). Acta Sci. Pol. Technol. Aliment. 2021, 20, 37-46.

11. Brzóska, F.; Śliwiński, B.; Michalik-Rutkowska, O. Effect of herb mixture on productivity, mortality, carcass quality and blood parameters of broiler chickens. Ann. Anim. Sci. 2010, 10, 157-165.

12. Wallace, R.J.; Oleszek, W.; Franz, C.; Hahn, I.; Baser, K.H.C.; Mathe, A.; Teichmann, K. Dietary plant bioactives for poultry health and productivity. Brit. Poultry Sci. 2010, 51, 461-487. [CrossRef] 
13. Ahmed, A.; Mangaiyarkarasi, R.; Shahid, N.; Umar, M.; Shahina, N.; Rahmanullah, S.; Zahra, Y. Effect of black tea extract (polyphenols) on performance of broilers. Int. J. Adv. Res. 2013, 1, 563-566.

14. Khan, S.H. The use of green tea (Camellia sinensis) as a phytogenic substance in poultry diets. Onderstepoort J. Vet. Res. 2014, 81, 1-8. [CrossRef] [PubMed]

15. Abdullah, A.Y.; Mahmoud, K.Z.; Nusairat, B.M.; Qudsieh, R.I. Small intestinal histology, production parameters, and meat quality as influenced by dietary supplementation of garlic (Allium sativum) in broiler chicks. Ital. J. Anim. Sci. 2010, 9, 414-419. [CrossRef]

16. Jahanian, E.; Mahdavi, A.H.; Asgary, S.; Jahanian, R. Effects of dietary inclusion of silymarin on performance, intestinal morphology and ileal bacterial count in aflatoxin-challenged broiler chicks. J. Anim. Physiol. Anim. Nutr. 2016, 101, e43-e54. [CrossRef]

17. Zaker-Esteghamati, H.; Seidavi, A.R.; Bouyeh, M. A review on the effect of Silybum marianum and its derivatives on broilers under healthy and aflatoxicosis conditions: Part 1: Performance, carcass and meat characteristics, and intestinal microflora. World Poult. Sci. J. 2020, 76, 318-327. [CrossRef]

18. Gregačević, L.; Klarić, I.; Domaćinović, M.; Galović, D.; Ronta, M. Fitogeni aditivi u hranidbi domaćih životinja. Krmiva 2014, $56,117-123$.

19. Stopyra, A.; Kuleta, Z.; Tomczyński, R.; Sobiech, P.; Kędzierska, K. Sylibum marianum in horses feeding. Ann. UMCS Lub. Polonia. Sect. DD 2006, LXI, 95-102.

20. Ahmad, M.; Chand, N.; Khan, R.U.; Ahmad, N.; Khattak, I.; Naz, S. Dietary supplementation of milk thistle (Silybum marianum): Growth performance, oxidative stress, and immune response in natural summer stressed broilers. Trop. Anim. Health Pro. 2020, 52, 711-715. [CrossRef]

21. Grela, E.R.; Świątkiewicz, M.; Florek, M.; Wojtaszewska, I. Impact of milk thistle (Silybum marianum L.) seeds in fattener diets on pig performance and carcass traits and fatty acid profile and cholesterol of meat, backfat and liver. Livest. Sci. 2020, $239,10418$. [CrossRef]

22. Sadowska, K. Fruits of milk thistle as a health-enhancing additive to bakery products. Zywn Nauk. Technol. Ja. 2006, 2, $290-296$.

23. Grela, E.R.; Pietrzak, K.; Pecka, S.; Sobolewska, S.; Krasucki, W. Ostropest plamisty w żywieniu zwierząt. Przeglad Hod. 2014, $5,38-40$.

24. Aziz, M.; Saeed, F.; Ahmad, N.; Ahmad, A.; Afzaal, M.; Hussain, S.; Mohamed, A.A.; Alamri, M.S.; Anjum, F.M. Biochemical profile of milk thistle (Silybum Marianum L.) with special reference to silymarin content. Food Sci. Nutr. 2021, 9, 244-250. [CrossRef] [PubMed]

25. Khan, I.; Khattak, H.U.; Ullah, I.; Bangash, F.K. Study of the physicochemical properties of Silybum marianum seeds oil. J. Chem. Soc. Pak. 2007, 29, 545-548.

26. Harrabi, S.; Romdhane, H.; Daassa, M.; Fellah, H. Fatty acid and triacylglycerol compositions of milk thistle seeds growing wild in Tunisia (Silybum marianum L.). Acta Aliment. 2015, 44, 304-310. [CrossRef]

27. Majidi, M.M.; Shafiei-Koij, F.; Pirnajmedin, F.; Jami, M.; Radan, Z. Fatty acid profile, silymarin content and production properties of milk thistle (Silybum marianum) germplasm under different water environments. Crop. Pasture Sci. 2021, 72, 302-310. [CrossRef]

28. Sadowska, K.; Andrzejewska, J.; Woropaj-Janczak, M. Effect of weather and agrotechnical conditions on the content of nutrients in the fruits of milk thistle (Silybum marianum L. Gaertn). Acta Sci. Pol. Hortorum Cultus 2011, 10, 197-207.

29. Kazazis, C.E.; Evangelopoulos, A.A.; Kollas, A.; Vallianou, N.G. The therapeutic potential of milk thistle in diabetes. Rev. Diabet. Stud. 2014, 11, 167-174. [CrossRef]

30. Szczucińska, A.; Lipkowski, A.W.; Baranowska, B.; Walisiewicz-Niedbalska, W.; Różycki, K.; Maciuszczak-Kotlarek, H. Utilisation of milk thistle seed waste. I. Milk thistle oil as antioxidant. Rośliny Oleiste Oilseed Crop. 2003, XXIV, 717-724.

31. Tedesco, D.; Steidler, S.; Galletti, S.; Tameni, M.; Sonzogni, O.; Ravarotto, L. Efficacy of silymarin-phospholipid complex in reducing the toxicity of aflatoxin $\mathrm{B}_{1}$ in broiler chicks. Poult. Sci. 2004, 83, 1839-1843. [CrossRef] [PubMed]

32. Bijak, M. Silybin, a major bioactive component of milk thistle (Silybum marianum L. Gaernt.) — chemistry, bioavailability, and metabolism. Molecules 2017, 22, 1942. [CrossRef] [PubMed]

33. Alhidary, I.A.; Rehman, Z.; Khan, R.U.; Tahir, M. Anti-aflatoxin activities of milk thistle (Silybum marianum) in broiler. World Poult. Sci. J. 2017, 73, 559-566. [CrossRef]

34. Ptasznik, A. The role of silymarin in prevention and treatment of liver diseases. Post. Fitoter. 2004, 4, 189-190.

35. Fanoudi, S.; Sadat Alavi, M.; Karimi, G.; Hosseinzadeh, H. Milk thistle (Silybum Marianum) as an antidote or a protective agent against natural or chemical toxicities: A review. Drug Chem. Toxicol. 2020, 43, 240-254. [CrossRef] [PubMed]

36. Valkova, V.; Duranova, H.; Bilcikova, J.; Haban, M. Milk thistle (Silybum marianum): A valuable medicinal plant with several therapeutic purposes. J. Microbiol. Biotechnol. Food Sci. 2020, 9, 836-843. [CrossRef]

37. Radko, L.; Cybulski, W. Application of silymarin in human and animal medicine. J. Pre. Clin. Clin. Res. 2007, 1, $22-26$.

38. Geberemeskel, G.A.; Debebe, Y.G.; Nguse, N.A. Antidiabetic effect of fenugreek seed powder solution (Trigonella foenumgraecum L.) on hyperlipidemia in diabetic patients. J. Diabetes Res. 2019, 5, 8507453. [CrossRef]

39. Nagy, J.; Such, N.; Koltay, I.A.; Molnar, A.; Farkas, V.; Dublecz, K.; Rozsa, L.; Pal, L. Health protecting effects of milk thistle (Silybum marianum) Literature review. Magy. Allatorvosok 2020, 142, 229-240.

40. Saadh, M.J. Hypoglycemic and hypolipidemic activity of combined milk thistle and fenugreek seeds in alloxan-induced diabetic albino rats. Vet. World. 2020, 13, 1732-1736. [CrossRef] 
41. Suchý, P.; Straková, E.; Kummer, V.; Herzig, I.; Písaříková, V.; Blechová, R.; Mašková, J. Hepatoprotective Effects of Milk Thistle (Silybum marianum) Seed Cakes during the Chicken Broiler Fattening. Acta Vet. Brno 2008, 77, 31-38. [CrossRef]

42. Muhammad, D.; Chand, N.; Khan, S.; Sultan, A.; Mushtaq, M. Hepatoprotective role of milk thistle (Silybum marianum) in meat type chicken fed aflatoxin $B_{1}$ contaminated feed. Pak. Vet. J. 2012, 32, 443-446.

43. Šrt'astník, O.; Detvanova, L.; Karásek, F.; Štenclová, H.; Kalhotka, L.; Pavlata, L.; Mrkvicová, E. The influence of milk thistle seed cakes on broiler chickens performance parameters. Mendel Net. 2015, 11, 152-156.

44. Gharahveysi, S.H. Effects of Milk Thistle Powder on Performance, Blood Parameters and Liver Enzymes of Broiler Chickens. J. Anim. Prod. 2017, 19, 879-889.

45. Mojahedtalab, A.; Mohammadi, M.; Roostaei Ali Mehr, M.; Asadi, M. Effect of silymarin on performance and immune responses of broilers. J. Anim. Physiol. Anim. Nutr. 2013, 2, 49-58.

46. Schiavone, A.; Righi, F.; Quarantelli, A.; Bruni, R.; Serventi, P.; Fusari, A. Use of Silybum marianum fruit extract in broiler chicken nutrition: Influence on performance and meat quality. J. Anim. Physiol. Anim. Nutr. 2007, 91, 256-262. [CrossRef] [PubMed]

47. Kralik, G.; Kralik, Z.; Straková, E.; Šperanda, M.; Kralik, I.; Strelec, I. Influence of dietary replacement of sunflower oil with milk thistle (Silybum marianum) oil on chicken meat quality and antioxidant status of liver. Acta Vet. Brno 2015, 84, 373-382. [CrossRef]

48. Št’astník, O.; Jůzl, M.; Karásek, F.; Štenclová, H.; Nedomová, Š.; Pavlata, L.; Mrkvicová, E.; Doležal, P.; Jarošová, A. The effect of feeding milk thistle seed cakes on quality indicators of broiler chickens meat. Potr. Slovak J. Food Ind. 2016, 10, 248-254. [CrossRef]

49. Rashidi, N.; Bujarpoor, M.; Chaji, M.; Aghaei, A. Effect of Silybum marianum seed on performance, carcass characteristics and blood parameters of broiler chickens. Anim. Prod. Res. 2015, 3, 11-21.

50. Janssen, W.M.M.A. European Table of Energy Values for Poultry Feedstuffs, 3rd ed.; Working Group No. 2 of the European Federation of BranchEs of the World's Poultry Science Association: Beekbergen, The Netherlands, 1989.

51. Ziołecki, J.; Doruchowski, W. The Method of Estimation of Poultry Slaughter Analysis; COBRD: Poznań, Poland, $1989 ;$ p. 22.

52. Vassiliou, A. Commission Regulation (EC) No 152/2009 of 27 January 2009 Laying Down the Methods of Sampling and Analysis for the Official Control of Feed; Official Journal of the European Union L 54/1: Brussels, Belgium, 26 February 2009.

53. AOAC. Official Methods of Analysis of the Association of Official Analytical Chemists, 15th ed.; Association of Official Analytical Chemists, Inc.: Washington, DC, USA, 1990; Chapter 32.

54. ISO 9831. Animal Feeding Stuffs, Animal Products, and Faeces or Urine-Determination of Gross Calorific Value-Bomb Calorimeter Method; International Organization for Standardization: Geneva, Switzerland, 2005.

55. Folch, J.; Lees, M.; Sloane Stanley, G.H. A simple method for the isolation and purification of total lipids from animal tissues. J. Biol. Chem. 1957, 226, 497-509. [CrossRef]

56. Ulbricht, T.L.V.; Southgate, D.A.T. Coronary heart disease: Seven dietary factors. Lancet 1991, 338, 985-992. [CrossRef]

57. Santos-Silva, J.; Bessa, R.J.B.; Santos-Silva, F. Effect of genotype, feeding system and slaughter weight on the quality of light lambs: II. Fatty acid composition of meat. Livest. Prod. Sci. 2002, 77, 187-194. [CrossRef]

58. Jurczak, M.E. Towaroznawstwo Produktów Zwierzẹcych: Ocena Jakości Mięsa; SGGW: Warszawa, Poland, 2005 ; pp. 117-119.

59. CIE. Draft Standard 014-4.3/E: Colorimetry_Part. 4: CIE $1976 L^{*} a^{*} b^{*}$ Colour Space; CIE Central Bureau: Vienna, Austria, 2007; p. 8.

60. Honikel, K.O. Reference methods for the assessment of physical characteristics of meat. Meat Sci. 1998, 49, 447-457. [CrossRef]

61. Milczarek, A.; Osek, M. Effectiveness evaluation of use of various protein feeds for broiler chicken feeding. Ann. Anim. Sci. 2019, 19, 1063-1081. [CrossRef]

62. Baryłko-Pikielna, N. Zarys Analizy Sensorycznej Żywności; WNT: Warszawa, Poland, 1975; pp. $183-188$.

63. Baryłko-Pikielna, N.; Matuszewska, I. Sensory Analysis of Food. Basics-Methods-Applications, 2nd ed.; Scientific Publishing PSFT: Kraków, Poland, 2014; pp. 166-180.

64. StatSoft Inc. Statistica (Data Analysis Software System), Version 13.1; StatSoft Inc.: Tulsa, OK, USA, 2019.

65. Hermenean, A.; Stan, M.; Ardelean, A.; Pilat, L.; Mihali, C.V.; Popescu, C.; Nagy, L.; Deák, G.; Zsuga, M.; Kéki, S.; et al. Antioxidant and hepatoprotective activity of milk thistle (Silybum marianum L. Gaertn.) seed oil. Open Life Sci. 2015, 10, 225-236. [CrossRef]

66. Růžičková, G.; Fojtová, J.; Součková, M. Výnos a kvalita oleje plodů ostropestřce mariánského (Silybum marianum (L.)) z pohledu prostředí a genotypu-Pilotní studie (The yield and quality of milk thistle (Silybum marianum (L). Gaertn.) seed oil from the perspective of environment and genotype-A pilot study). Acta Fytotech. Zootech 2011, 1, 9-12.

67. Andrzejewska, J.; Sadowska, K.; Mielcarek, S. Effect of sowing date and rate on the yield and flavonolignan content of the fruits of milk thistle (Silybum marianum L. Gaertn.) grown on light soil in a moderate climate. Ind. Crop. Prod. 2011, 33, 462-468. [CrossRef]

68. Wierzbowska, J.; Bowszys, T.; Sternik, P. Effect of mineral fertilization on the content and quality of fat in the achenes of milk thistle (Sylibum marianum L. Gaertner). Rośliny Oleiste Oilseed Crops 2012, XXXIII, 99-111.

69. Garaev, E.A.; Movsumov, I.S.; Gazizov, F.Y. Neutral lipids from Silybum marianum seeds. Chem. Nat. Compd. 2010, 46, 629-630. [CrossRef]

70. Hasanloo, T.; Bahmanei, M.; Sepehrifar, R.; Kalantari, F. Determination of tocopherols and fatty acids in seeds of Silybum marianum (L.) Gaerth. J. Med. Plants 2008, 7, 69-75.

71. Kalantar, M.; Salary, J.; Nouri Sanami, M.; Khojastekey, M.; Hemati Matin, H.R. Dietary supplementation of Silybum marianum or Curcuma spp. on health characteristics and broiler chicken performance. Glob. J. Anim. Sci. Res. 2014, 2, 58-63.

72. Śliwa, J.; Brzóska, F. Effect of diets with non-GM soybean expeller on body weight, carcass quality and amino aciddigestibility in broiler chickens. Rocz. Nauk. Zootech. 2018, 45, 59-87. 
73. Nowak, M.; Trziszka, T. Consumer behavior on the poultry meat market. Zywn Nauk. Technol. Ja. 2010, 1, 114-120.

74. Tougan, P.U.; Dahouda, M.; Salifou, C.F.; Ahounou, S.G.; Kpodekon, M.T.; Mensah, G.A.; Thewis, A.; Karim, I.Y. Conversion of chicken muscle to meat and factors affecting chicken meat quality: A review. Int. J. Agron. Agric. Res. 2013, 3, 1-20.

75. Zdanowska-Sąsiadek, Ż.; Michalczuk, M.; Marcinkowska-Lesiak, M.; Damaziak, K. Factors determining the sensory quality of poultry meat. Bromatol. Chem. Toksyk. 2013, LVI, 344-353.

76. Rycielska, J.; Jarosiewicz, K.; Słowiński, M. Influence of selected pre-slaughter factors on chicken meat quality. Med. Weter. 2010, $66,770-773$.

77. Kunachowicz, H.; Nadolna, I.; Przygoda, B.; Iwanow, K. Food Composition Tables; PZWL: Warszawa, Poland, 2017.

78. Magdelaine, P.; Spiess, M.P.; Valceschini, E. Poultry meat consumption trends in Europe. World Poult. Sci. J. 2008, 64, 53-63. [CrossRef]

79. Mehaffey, J.M.; Pradhan, S.P.; Meullenet, J.F.; Emmert, J.L.; McKee, S.R.; Owens, C.M. Meat quality evaluation of minimally aged broiler breast fillets from five commercial genetic strains. Poult. Sci. 2006, 85, 902-908. [CrossRef]

80. Janocha, A.; Milczarek, A.; Pietrusiak, D.; Łaski, K. The effect of rations containing hulled or hull-less barley on the slaughter parameters and the quality of broiler chicken meat. J. Cent. Eur. Agric. 2020, 21, 508-516. [CrossRef]

81. Gornowicz, E.; Pietrzak, M. Carcasse yield and breast muscles quality as affected by broiler chicken origin. Rocz. Inst. Przem. Mięs. Tt. 2008, 46, 95-104.

82. Milan, R.; Klaus, D. The meaning of $\mathrm{pH}$-value for the meat quality of broilers-Influence of breed lines. Tehnologija Mesa 2010, 51, 120-123.

83. Milan, R.; Hansgeorg, H.; Klaus, D. Meaning of the pH value for the meat quality of broilers. Fleischwirtschaft 2011, 91, 89-93.

84. Van Laack, R.L.J.M.; Liu, C.H.; Smith, M.O.; Loveday, H.D. Characteristics of pale, soft, exudative broiler breast meat. Poult. Sci. 2000, 79, 1057-1061. [CrossRef] [PubMed]

85. Komprda, T.; Zelenka, J.; Drobná, Z.; Jarošová, A.; Fajmonová, E. Sensory quality of meat of turkeys fed the diet with sunflower, linseed or fish oil. Arch. Geflugelkd. 2003, 67, 225-230. 